\section{Penúltimas palavras}

Helgio Trindade (org.). Ciências Sociais no Brasil: diálogos com mestres e discípulos. São Paulo, Anpocs/ Liber Livro, 2012. 366 páginas.

\section{José de Souza Martins}

Um livro como Ciências sociais no Brasil: diálogos com mestres e discípulos, organizado por Helgio Trindade, patrocinado pela Anpocs e publicado pela editora Liber Livro, tem tudo para despertar a curiosidade de quem se interessa pelo lugar da autobiografia intelectual de personagens do caminho percorrido no país por profissionais desta nossa área de conhecimento, ${ }^{1}$ não só pelos diálogos anunciados, mas também pelos monólogos. Quinze pesquisadores que quase todos nós chegamos a conhecer pessoalmente, cujas vozes ouvimos e cujos textos lemos, estão ali reunidos pela amostra casual e macabra da morte. Subsídio "para os que querem entender a evolução e a dinâmica das ciências sociais no Brasil”, como assinala Marcos Costa Lima na apresentação do livro.

As quinze entrevistas são apenas pálida amostra de um universo que envolve 576 cientistas sociais no Brasil e chega a 724 entrevistas na América Latina (p. 12). Um trabalho imenso, artesanal e não quantitativo, o que bem indica obra de extenso labor e muita paciência. Ainda assim, ficariam de fora nomes de grande relevo no panorama das ciências sociais em nosso país porque de pessoas falecidas antes de Trindade lançar-se no projeto, como Florestan Fernandes, Marialice Mencarini Foracchi, Ruy Coelho, Azis Simão, Herbert Baldus, Oracy Nogueira, em São Paulo; Mauricio Vinhas de Queiroz, Luiz Costa Pinto, no Rio de Janeiro; Gilberto Freyre, no Recife; Thales de Azevedo, em Salvador; Eduardo Galvão, no Pará; entre tantos outros. A amostra tem esse viés.

O volume não comporta uma resenha convencional, pela natureza mesma do livro e das polêmicas que pode suscitar. Pede, antes, um artigo sobre temas e problemas ali contidos. Apesar de seu extremo interesse, pede uma leitura cautelosa e crítica, que lhe assinale limites e limitaçóes e nele destaque as informaçóes que forem relevantes na elaboração de um grande painel dos processos e dilemas constitutivos das ciências sociais no país. Pede, também, considerações sobre os faits divers e o anedótico no mundo acadêmico, nem sempre inocentes ou divertidos.

Há uma diferença em relação a outros livros de temática idêntica: vários entrevistados, por aparentemente não saberem que suas entrevistas seriam publicadas, puseram-se à vontade para externar opiniōes pessoais sobre colegas, opiniōes que não ousariam externar diante dos atingidos. Nesse sentido, há no livro um curioso resvalo para o irrelevante dos supostos bastidores da vida acadêmica. Vários optaram por falar de pessoas e não de fatos nem de ideias. Com essas opiniōes, não raro descabidas, nada acrescentam ao conhecimento do tema que identifica o livro. Esse é, certamente, um dos aspectos complicados desta obra. Minha franca esperança é de que os leitores do livro se deem conta de que se trata de um cometimento inicial revelando as eventuais anomalias de um retrato que não reflete ainda e plenamente a ousada e criativa trajetória dos cientistas sociais brasileiros. São décadas de um extenso ganho, durante as quais elaboramos um retrato explicativo e interpretativo do Brasil e uma densa e fundamentada consciência sociológica da sociedade brasileira.

$\mathrm{Na}$ Introdução, Trindade deixa claro que seu intuito foi o de reunir depoimentos para construir um perfil dos cientistas sociais brasileiros e das ciências sociais no Brasil, situando-o no contexto social e político em que as biografias intelectuais de seus personagens se formaram. Dos quinze, seis foram antropólogos, cinco foram sociólogos e quatro, cientistas políticos. Talvez o acaso da morte tenha tornado esses depoimentos menos representativos do que os de uma seleção em que o critério fosse outro, propriamente científico. É o que talvez explique a dificuldade, que se vê na Introdução do organizador, para encontrar um padrão, um fio condutor, que ponha alguma coerência na dispersão inevitável. A tarefa do entrevistador e organizador do livro não foi fácil. Nem por isso foi menos significativa.

A diversidade de origens sociais dos entrevistados constitui um fascinante tema a ser desdobrado e explorado em conexão com o teor e a visão de mundo expressos em suas respectivas obras. Mas 
analisado, também, nas diferenças sociais e históricas que separam e opõem, mais do que juntam, as personagens deste pequeno elenco de colegas já falecidos. Quanto o modo de ver de nossos cientistas sociais reflete o modo de ser de seus grupos de origem em precedência aos estritos e demarcados princípios da produção do conhecimento científico? Quanto o senso comum da cultura de classe e de origem invade a ciência?

Uma dificuldade na comparação é que, nesse grupo, não há ninguém originário, propriamente, das "classes populares", como seria o caso de Florestan Fernandes e, talvez, o de Gioconda Mussolini, cujo centenário ocorreu em 2013, aluna de Claude Lévi-Strauss, citada em Tristes trópicos, filha de um imigrante italiano. Seu pai era trabalhador de fábrica no bairro do Brás. Ela era uma antropóloga brilhante e erudita e uma professora extraordinária. Fui seu aluno. Teve a carreira bloqueada pelos desestímulos da cultura machista da universidade. Gioconda, aliás, era mulata, o que procurava ocultar. Na nova linguagem de hoje, na decorrente nomenclatura e na reclassificação social falsamente precisa que expressa, foi ela a primeira negra a fazer parte do corpo docente da Faculdade de Filosofia e, provavelmente, de toda a Universidade de São Paulo.

Teria sido interessante analisar, na introdução do livro, quanto a isso, o modo de falar e de exprimir-se dos entrevistados, as relevâncias que escolheram para a estrutura, o teor e o tom de seus discursos. Tema que aponta a enorme diferença social que há entre Lygia Sigaud e Carlos Estevam Martins, de um lado, e Heleieth Bongiovanni Saffioti e Antonio Flávio Pierucci, de outro. Por uma questão analítica e metodológica, polarizo e comparo os dois pares, que tomo como socialmente extremos. Os dois últimos extraviam-se em considerações pessoais depreciativas sobre colegas, sem estabelecer uma conexão com o que seria seu próprio lugar de personagens da história da ciência entre nós. É o oposto com Lygia e Estevam, cujos discursos refletem outra mentalidade e a alta origem social de ambos. Ela, tetraneta de um médico francês da família real portuguesa no Brasil, descendente de fazendeiros, filha de pelo menos cinco geraçôes de gente culta. Ele, igualmente descendente de francês vindo para o Brasil no Império, de família de fazendeiros do sul de Minas Gerais e do Rio de Janeiro, da mesma linhagem do marquês de Valença, seu antepassado fluminense, com ramificações em São Paulo. Também, pelo menos, cinco gerações de gente culta. Os dois tiveram alta educação e beneficiaram-se da vida vibrante do Rio de Janeiro cosmopolita, uma vida educativa em si mesma.

Heleieth Saffioti e Flávio Pierucci são paulistas, de um perfil provinciano, na linguagem e na mentalidade, algo bem característico de boa parte dos paulistas, cujos depoimentos estão neste livro, se comparados com os dos cariocas. Essa é uma das interessantes revelações do livro, os de São Paulo mais introspectivos, de relacionamentos pessoais mais difíceis na universidade, tendentes a expressar uma tensão destrutiva.

Ambos eram descendentes de imigrantes italianos. Ela, neta de um bolonhês que se tornou dono de fábrica de macarrão no interior e filha de um empreiteiro de obras. Sua avaliação de seus professores na USP é amplamente corrosiva. Diz-se amiga de quase todos e em relação a todos emite juízos depreciativos. Num certo momento afirma: "Acho que não tive bons professores" (p. 141). E ela foi aluna de Florestan Fernandes, Antonio Candido, Maria Isaura Pereira de Queiroz, Fernando de Azevedo, Paula Beiguelman! Emite na entrevista conceitos sobre cientistas sociais conhecidos, definindo a cada um como chato, horrível, deletério. Sobre si mesma, diz mais de uma vez que sempre foi a primeira da classe. Politicamente, diz-se de esquerda, de esquerda radical. É a única dos entrevistados que precisa dizer isso.

Diferentemente dos cariocas do livro, de biografias intelectuais e políticas muito ricas, especialmente a de Carlos Estevam Martins, Heleieth mostra um traço muito próprio do imigrante, ainda no caminho da busca de um lugar definitivo na sociedade de adoção, sem clareza sobre os outros e sobre si mesma, desconfiada.

Os do Rio de Janeiro são dotados de uma consciência de membros, de pertencimento social, o que nos oriundi de São Paulo se nota pouco, com exceção do caso de Octavio Ianni (e o de Ruth Cardoso e Juarez Brandão Lopes, que não eram de ascendência imigrante). Os de São Paulo dão a im- 
pressão de que estão fora do lugar. Algo que nos descendentes de imigrantes tem se estendido por pelo menos três gerações, uma assimilação problemática e mais lenta do que se pensa. Um indício muito peculiar de que a tão propalada ascensão social, dos estudos sociológicos e antropológicos sobre o imigrante, constitui um processo desigual, a mesma pessoa vivendo momentos desencontrados desse processo. Chega à universidade sem ter saído da aldeia de origem de pais e avós.

Antônio Flávio Pierucci também era neto de italiano, um imigrado para a região cafeeira da Alta Mojiana, em São Paulo. Bisavô cervejeiro, avô músico e pai funcionário público. Diversamente do que aconteceu com a maioria dos imigrantes naquela região, trabalhadores pobres, não era de família de colonos de café, de trabalhadores rurais, mas antes da baixa classe média imigrante e relativamente inculta, dos que vieram fazer a América, a vida mais centrada no ganhar do que no saber. No entanto, Pierucci foi beneficiado por uma característica cultural do imigrante italiano e seus descendentes que tem sido a de oferecer um filho ao sacerdócio. Um seguro meio pré-moderno de ascensão social que, por sua força simbólica, alcança a família inteira. Esse ainda é um traço histórico de atitude perante a vida dos descendentes de italianos e alemães no sul do Brasil, justamente por isso considerado o celeiro das vocações religiosas no país.

Pierucci não fez ciências sociais, o que atenua a probabilidade de uma consciência de pertencimento nos grupos em que viria a se inserir. Fez filosofia na Pontifícia Universidade Católica (PUC) e depois teologia na Universidade Gregoriana de Roma. Desistiu de ser padre no limiar da ordenação sacerdotal. Ingressou no Cebrap como revisor de textos (gabava-se de seu conhecimento de latim e grego) e, depois, auxiliar de pesquisa. Participou da equipe de tradução brasileira da Bíblia de Jerusalém. Só ali, no contato com Cândido Procópio Ferreira de Camargo, um especialista em sociologia da religião, acabaria decidindo fazer o mestrado em ciências sociais na PUC-SP. Seu depoimento autobiográfico reflete a cultura corporativa e fechada de quem teve formação eclesiástica e foi socializado nos parâmetros limitantes do que Goffman chama de instituição total, o seminário.
Tanto no depoimento de Heleieth quanto no de Pierucci, as referências aos outros expressam o temor dos oriundi de que os outros estão ali para lhes tomar o pouco que têm. Expressam esse temor minimizando os demais. Algo que observei em minhas pesquisas sobre a imigração italiana e a espanhola, um traço da personalidade do imigrante.

As entrevistas de Lygia Sigaud e de Gilberto Velho são excepcionalmente boas, de verdadeiros scholars, centradas na missão intelectual, na vocação, no chamamento, no que é próprio do pesquisador que se assume plenamente como educador. Não são as únicas no elenco de nomes do livro. Nos dois, a competência explícita para centrar a narrativa não na pessoa, mas na busca do conhecimento, um avanço pedindo e propondo outro avanço, a ciência como meta, como ponto de partida e ponto de chegada.

Há muita generosidade nessas falas. Gilberto faz justiça à dona Marina São Paulo de Vasconcelos, que foi diretora do Instituto de Ciências Sociais da Universidade Federal do Rio de Janeiro, onde a conheci. Ela pagou um alto preço por sua coerência e sua lealdade às próprias ideias e aos colegas em face da repressão política da ditadura militar. Foi presa.

Gilberto faz justiça, ainda, a Maurício Vinhas de Queiroz, de quem fui auxiliar de pesquisa, e ele também, no mesmo Instituto. Ele não menciona, mas Maurício fez uma decisiva e original pesquisa sobre a Guerra do Contestado (1912-1916). Nos anos de 1950, percorreu a cavalo toda a região, em Santa Catarina, à procura de sobreviventes e testemunhas do movimento messiânico que ali se desenrolara. Anotou à mão um grande número de depoimentos e reuniu documentos importantes. $\mathrm{O}$ material destinava-se à sua tese de doutorado. A demora na institucionalização do doutorado na Universidade do Brasil, depois Universidade Federal do Rio de Janeiro (UFRJ), inviabilizou a defesa da tese. Acabou publicando-a sem defendê-la (Messianismo e conflito social). Foi generoso: cedeu todo seu material a Maria Isaura Pereira de Queiroz, da USP, orientanda de Roger Bastide, que em boa parte com ele faria sua tese (Le mouvement messianique $d u$ Contestado). Maria Isaura, por sua vez, cederia o material de Maurício a Duglas Teixeira Monteiro, que o utilizou em sua premiada tese de doutorado: 
Os errantes do novo século. Maurício faria seu doutorado mais tarde, na USP, com Luiz Pereira, sobre Grupos econômicos no Brasil, baseado em volumosa e original pesquisa que identificou pela primeira vez os grupos econômicos multibilionários brasileiros e estrangeiros aqui instalados, a história de sua acumulação originária e suas interconexões, a etnografia do capitalismo no país. Como se vê numa citação de Caio Prado Júnior, a pesquisa de Maurício mostrou o descabimento de uma tese deformante na história das ciências sociais no Brasil, a de um feudalismo brasileiro. Depois de se aposentar na Universidade de Brasília, Maurício morreria cego, quando morava sozinho num barraco de uma praia do Rio de Janeiro. Mergulhador, amava o mar.

Destaco duas entrevistas de São Paulo, igualmente notáveis: a de Octavio Ianni e a de Juarez Rubens Brandão Lopes. Embora Ianni também fosse filho de italianos, de um tripeiro radicado em Itu, era um intelectual, de família que tinha outros intelectuais, como Constantino Ianni, seu irmão, economista e autor de Homens sem paz, um original livro sobre a imigração italiana. Para escrevê-lo, refez num navio de imigrantes a viagem de seus pais para o Brasil. Octavio Ianni foi gráfico, o que o coloca na linhagem de Machado de Assis. Ele assume a entrevista como um depoimento que enriquece as perguntas do entrevistador. Conduz, não é conduzido. Não aceitou a intenção subjacente às perguntas que pretendiam induzi-lo a fazer considerações de ordem pessoal sobre colegas. Nas respostas, levou-as ao terreno apropriado de um testemunho sobre a sociologia na USP. É um belo e esclarecedor depoimento sobre a história intelectual do grupo que se constituiu ao redor de Florestan Fernandes e da herança de Roger Bastide.

Juarez, entre nós pioneiro da sociologia da indústria e do trabalho, é de uma família de políticos de Minas Gerais. O avô paterno era médico e foi senador estadual. Do lado materno, Júlio Bueno Brandão foi governador do Estado duas vezes. O depoimento de Juarez tem uma importância particular. Estudou na Escola de Sociologia e Política de São Paulo, foi assistente de Mário Wagner Vieira da Cunha, weberiano que fundou o Instituto de Administração da Faculdade de Economia da USP, foi professor de sociologia na Faculdade de Arquitetura e Urbanismo da USP, mais tarde no Departamento de Ciências Sociais da Faculdade de Filosofia da USP e se integrou ao grupo do Cebrap. Essa multiplicidade de situaçôes e experiências o pôs em contato com um número de sociólogos, antropólogos e cientistas políticos de São Paulo bem maior que o mencionado por membros de grupos mais restritos e mais localizados. A história de Juarez é uma verdadeira excursão pela diversidade das nossas ciências sociais. Em seu depoimento não há restrições a pessoas nem ressentimentos, apenas a palavra de uma grande e serena testemunha, expressão de uma rica diversidade de momentos da história das ciências sociais em São Paulo, ponto de vista de um pesquisador característico do establishment acadêmico norte-americano, que muito o influenciou.

No entanto, vários dos entrevistados expressaram, também, suas mágoas, no geral como vítimas da cátedra e do poder pessoal que marcaram nossas instituições acadêmicas em seus primeiros tempos, citando nomes de destaque de nossas universidades. Mas outros testemunharam o quanto nossas ciências sociais devem a pequenas e tópicas providências de pessoas de grande lucidez, que abriram caminho num cenário no geral hostil ao que as ciências sociais representavam e representam.

Em vários casos, Helgio Trindade fez perguntas a seus entrevistados sobre o modo como a Igreja Católica tentou instrumentalizar o magistério das Faculdades de Filosofia e das Ciências Sociais. Fê-lo nas perguntas a Sílvio Coelho, já que em Santa Catarina havia evidências de um possível cerceamento. Aparentemente, Trindade elegeu o caso muito particular do Rio de Janeiro como referência do que foi ali o controle católico sobre a Faculdade Nacional de Filosofia. No entanto, o caso do Rio não foi um modelo. Como Ruth Cardoso fora aluna do Colégio das Cônegas de Santo Agostinho, Trindade procurou saber por meio dela como teria sido a disputa católica pela Faculdade de Filosofia da USP. Mas Ruth fez parte daquela geração que, mesmo tendo estudado em colégio religioso, não ficou sob influência católica. Aparentemente, não considerava o assunto relevante, já que sua Faculdade se manteve completamente distante do assédio. Não era a pessoa que poderia esclarecer esse assunto para o entrevistador. 
Trindade, portanto, não obteve esclarecimentos sobre a resistência à oculta tentativa de catolicizar a universidade pública paulista. Em São Paulo, a questão se pôs de modo completamente diferente do ocorrido no Rio de Janeiro, não obstante os esforços do arcebispo dom Duarte Leopoldo e Silva no sentido de fazer da Faculdade de Filosofia uma escola de influência católica. Júlio de Mesquita Filho, o principal idealizador da USP, cuja família era dona do jornal $O$ Estado de S. Paulo (o cunhado, Armando Salles Oliveira, era o governador do Estado e criaria a USP), era homem de formação positivista e um leitor de Durkheim. A redação do jornal foi o ponto de encontro de intelectuais de orientação liberal e alheios às pretensões da Igreja na questão da educação, os que se envolveram no projeto de criação da USP.

Mais tarde, no fim dos anos de 1950 e início dos de 1960, a redação do jornal foi abrigo importante da Campanha em Defesa da Escola Pública, em face de um projeto de Lei de Diretrizes e Bases da Educação que favorecia a escola privada na educação nacional. Na campanha, destacaram-se Florestan Fernandes, Laerte Ramos de Carvalho, João Baptista Borges Pereira, Fernando Henrique Cardoso, Octavio Ianni e vários outros docentes da USP e de outras universidades. Como me explicou Florestan, poucos dias antes de morrer, foi decisivo na Campanha o apoio das igrejas protestantes, dos espíritas e, sobretudo, da maçonaria.

Decidida a criação da Universidade, foi enviado à Europa o professor Theodoro Ramos, da Escola Politécnica, matemático e estatístico, positivista filiado à Igreja Positivista do Brasil para recrutar os docentes que formariam a Faculdade de Filosofia Ciências e Letras, instituição central da nova universidade, a USP. Na França, a constituição da Missão Francesa, núcleo da nova escola, teve a interferência decisiva de George Dumas, que conhecia o Brasil e era amigo de Mesquita. Dumas era protestante.

Intencionalmente ou não, na formação da Faculdade de Filosofia da USP houve uma participação decisiva de não católicos, ainda que a aula inaugural da USP tenha sido dada pelo geógrafo Pierre Deffontaines, ativista da Ação Católica. Claude Lévi-Strauss, da cátedra de Sociologia, era judeu. Roger Bastide e Paul-Arbousse Bastide (não eram parentes) eram protestantes. Uma linhagem protestante formou-se na área de ciências sociais. $\mathrm{Na}$ linguística, o brasileiro recrutado para iniciá-la foi Otoniel Mota, um gramático, escritor e pastor presbiteriano, amigo e membro da mesma igreja do renomado gramático Eduardo Carlos Pereira. Ali foram protestantes os linguistas por várias gerações. João Baptista Borges Pereira, a quem devo as informações sobre o tema, é o melhor conhecedor dessa presença dos protestantes na Faculdade de Filosofia, ainda hoje. Na USP, a abertura crítica, como opção rigorosa pelos valores da ciência, deve ser creditada ao positivismo e ao protestantismo e não ao marxismo, que ali chegou tardiamente e que não é necessariamente crítico. ${ }^{2}$ Não é estranho que Florestan Fernandes tenha dito que, num país como este, mesmo o positivismo é revolucionário.

Certamente, há nas entrevistas graus variáveis de desinformação dos entrevistados em referências equivocadas a fatos e pessoas. A olho nu, posso identificar várias. Em relação a mim mesmo, constato equívocos graves de três entrevistados. São informações e afirmações inverídicas, e até caluniosas, com alta probabilidade de dano moral, que não podem ficar sem contestação detalhada e incisiva. Um descuido, na publicação de um livro como este. Contesto-os em defesa própria, mas também para mostrar o quanto entrevistas não submetidas à verificação e ao confronto com outras fontes podem ser enganosas e danosas e, por isso, devem ser relativizadas e até descartadas pelo pesquisador, se necessário. Nem tudo o que um morto disse é necessariamente relevante. A morte só legitima no mundo da crendice.

Maria do Carmo Campello de Souza, que foi professora de ciência política na Faculdade de Filosofia da USP, minha colega e amiga das conversas amenas ao balcão do cafezinho, foi presa em 1970. $\mathrm{Na}$ verdade, foi sequestrada no estacionamento da escola por agentes da repressão, após as aulas do curso noturno, quando ainda estávamos nos barracôes provisórios na Cidade Universitária, depois de termos sido violentamente expulsos da rua Maria Antônia, em 1968. Fora denunciada por sua empregada doméstica, que estava apaixonada por seu marido (pp. 197-198). Entre a sala de aula e o es- 
tacionamento, nessa noite, uma aluna a seguia de perto. Ao ser presa, a aluna embarcou num dos carros com um dos policiais (p. 197). Carmute nem cita o nome da aluna. No final de 1975, organizei um Painel de Sociologia da Vida Cotidiana, com a participação de vários professores da USP e de fora. Pouco antes da conferência de abertura, no lotado auditório do Instituto de Psicologia, um dos alunos me alertou para a presença de um simpático casalzinho de supostos estudantes, sentado lá no meio: "São da polícia", avisou. Algumas semanas depois, vários dos conferencistas foram intimados a comparecer ao Dops e interrogados sobre o que haviam dito. Quando, no governo Franco Montoro, tive acesso à minha ficha no Dops, não me surpreendi ao constatar que ela não se limitava à minha prisão e fichamento em 1966, quando fui detido junto com Roberto Schwartz, assistente do professor Antonio Candido. Na ficha havia um conjunto de anotações estapafúrdias, aparentemente feitas em sala de aula por alunos que eram agentes infiltrados, gente que delatava colegas e professores por alguns trocados.

Carmute passou cerca de um ano presa, inicialmente no Dops, foi "maltratada" na Oban e depois levada para o presídio Tiradentes. Quando saiu, foi à faculdade e sobre isso disse: "o chefe do departamento, José de Souza Martins, me disse que eu tinha faltado muito e que eu tinha que repor. Falei que não tinha condições de repor nem de dar uma aula, era muita pressão e medo" (p. 201). A informação é completamente falsa. Nunca daria esse conselho a ninguém, até porque sem pé nem cabeça: funcionário público ausente por mais de trinta dias, sem afastamento regular, é demitido administrativamente. Isso não aconteceu com Carmute e não tenho a menor ideia de como foi resolvida a questão de sua prolongada "ausência". Como aconteceu em outros casos, algum acerto interno foi feito, alguém correndo o risco do acobertamento de uma situação involuntariamente irregular. Além do que nunca fui chefe de departamento, diretor de faculdade ou reitor da Universidade. Na USP, essas funções só podem ser ocupadas por professores titulares. ${ }^{3}$ Eu só faria o concurso para titular em 1998, 28 anos depois da prisão da Carmute, e só assim me habilitaria para ocupar uma dessas funções administrativas, o que nunca pretendi. Nem mesmo fui membro dos colegiados, como conselho departamental, congregação ou conselho universitário.

Das duas uma: ou ela estava muito perturbada, o que era compreensível tendo em conta o que passou ("Eu estava tão biruta que fui para uma clínica de repouso...", p. 200) ou meu nome foi enxertado na transcrição da entrevista por erro de quem a degravou ou por ter indevidamente presumido o que ouvia. Para fazer essa suposição, baseio-me em outros erros desse tipo no livro. $\mathrm{O}$ mais significativo descuido está na entrevista de Juarez Brandão Lopes. Mais de uma vez, há referência a um Berton Hudson (p. 52 e 67), que nunca existiu. Juarez está se referindo ao sociólogo inglês Bertram Hutchinson, especialista em mobilidade social, que trabalhou no Centro Brasileiro de Pesquisas Educacionais e por ele publicou um livro referencial: Mobilidade e trabalho, em 1960. Há outros descuidos com relação a nomes: $\mathrm{Na}$ entrevista de Maria D'Alva Kinzo, é citada uma Maria Conceição Quintela (p. 336), que é na verdade Maria da Conceição Quinteiro, socióloga formada pela USP, autora das extraordinariamente bem feitas entrevistas com posseiros do sul do Pará, em pesquisa do Cebrap, utilizadas por Octavio Ianni em seu livro A Luta pela terra. Maria D'Alva não erraria esse nome, de sua colega de trabalho.

Sou também "citado" na entrevista de $\mathrm{He}$ leieth Bongiovanni Saffioti, que foi professora de sociologia em Araraquara. Ela começa chamando Francisco Weffort de trânsfuga. Imediatamente vai para cima do meu nome, atribuindo-me o mesmo qualificativo. Diz que teria dito à minha mulher, num almoço em Fortaleza (p. 141): "Eu não entendo o que aconteceu com o Martins (José de Souza), ele era PT, de esquerda, marxista, e agora está num conservadorismo!" Nunca fui membro de partido político, fosse o PT ou fosse qualquer outro. Poderia ter sido, era e é meu direito, como era e é meu direito não pertencer a nenhum. Como narro em meu livro de memórias acadêmicas $A$ sociologia como aventura, muito antes da fundação do PT fui convidado por Lula para uma conversa num sábado à tarde na Casa Paroquial de São Bernardo do Campo. Ele queria que eu lhe relatasse como era 
a situação social e política no campo e lhe expusesse minhas constataçóes na pesquisa que fazia sobre os conflitos na região amazônica. Conversamos durante uma tarde inteira. Lula, entre os políticos brasileiros, é, provavelmente, o ouvinte mais atento e está certamente entre os mais inteligentes. Ouviu muito e fez perguntas pertinentes.

Tempos depois, já na fase de organização do Partido dos Trabalhadores (PT), convidou-me para uma reunião no Centro de Estudos de Cultura Contemporânea (Cedec), em São Paulo. Lá estavam Perseu Abramo, Francisco Weffort, José Álvaro Moisés, Maria da Conceição d'Incao, entre outras pessoas. Lula pediu-me para ajudar o partido a preparar uma cartilha que explicasse aos trabalhadores rurais, do ponto de vista do PT, o que era a questão agrária e o que fazer. Expliquei-lhe que não era membro do PT nem pretendia ser. Eu estava envolvido numa pesquisa complicada em região muito violenta, além do mais dividida partidariamente: no Mato Grosso, os agentes de mediação da Igreja e dos sindicatos estavam alinhados com o Movimento Democrático Brasileiro (MDB); no Pará, esses mesmos agentes estavam alinhados com o Partido Comunista do Brasil (PCdoB). Eu optara pela prudente linha de Florestan: a conselho de Hermínio Saccheta, ele deixou de fazer parte da organização trotsquista para ser apenas sociólogo e só voltou à política quando, anistiado, decidiu não retornar à universidade. Entrou para o PT com uma relutância que comunicou a Lula diante da comissão de notáveis que foi à sua casa convidá-lo a filiar-se ao partido: "Filio-me se você me garantir que o PT não é um partido de direita”. Ouvi isso de Antonio Candido, que estava lá e era seu amigo dileto.

Lula me disse, então, que isso não fazia a menor diferença, não importava se era ou não membro do PT. Pedia minha ajuda na preparação do documento. Disse-lhe que o PT, um partido operário, não tinha uma posição sobre o assunto e rigorosamente falando nada tinha a dizer de seu aos trabalhadores rurais. O PT deveria, antes, ouvir a diversidade dos trabalhadores do campo, para se posicionar e para se munir do material que lhe permitisse preparar um documento com a função pretendida. Ele concordou e respondeu-me que o grupo de assuntos rurais do partido entraria em contato comigo. $\mathrm{O}$ encontro nunca se realizou: nunca me procuraram. Os militantes petistas que estudavam o mundo rural estavam naturalmente mais interessados na questão trabalhista no campo e a ela limitados, os chamados boias-frias e clandestinos, os operários do campo, do que na questão agrária, os camponeses que lutavam pelo direito à terra e não por direitos trabalhistas. Naquele momento, havia um único conflito trabalhista mais intenso na agricultura, o dos boias-frias de Guariba (SP). No mesmo momento, havia mais de dez mil litígios envolvendo posseiros em todo o Brasil. O PT que nascia, ainda que informado por sociólogos de sua militância, estava completamente alheio à extensa diversidade das lutas sociais no campo.

Em várias ocasiōes, Lula recomendou a grupos locais petistas, de diferentes regiōes, que conversassem comigo. Mas logo ficou evidente que petista só conversa com petista. Vinham me procurar e quando lhes dizia que poderíamos conversar, mas que eu não era petista, a conversa terminava ali mesmo. Lula também sugeriu a Jair Meneghelli que me convidasse para uma conversa com a Central Única de Trabalhadores (CUT). Passei um dia inteiro em São Bernardo do Campo, no lotado auditório do sindicato dos metalúrgicos, fazendo extensa e detalhada exposição, para os sindicalistas, sobre a questão social no campo. A CUT era essencialmente urbana e foi muito grande a surpresa com que me ouviram sobre um conflito social disseminado em extenso território, muitíssimo além das portas de fábrica e completamente diferente do que conheciam e do que entendiam ser as relações de trabalho no Brasil.

Do mesmo modo, quando Raul Jungmann assumiu o Ministério de Desenvolvimento Agrário, procurou-me para conversar e por minha sugestão passou a procurar pesquisadores de diferentes universidades, sem vinculação partidária ou vinculados a diferentes partidos, mesmo ao PT. Conversava com grupos heterogêneos. Muito rapidamente ele se tornou uma das pessoas mais bem informadas do país sobre as questôes sociais do campo. Mantivemos contato durante todo o tempo em que foi ministro. Ele comparecia a essas reuniōes com um caderno, fazia perguntas, pedia críticas e tomava nota de tudo. Leu os principais autores do tema e 
promoveu conferências no Instituto Nacional de Colonização e Reforma Agrária (Incra) e no Ministério. Seu principal apoio foi o Núcleo de Estudos Agrários e Desenvolvimento Rural (Nead), dirigido por Juarez Brandão Lopes, um sociólogo que separava criteriosamente a ciência da política. Coisa que outros, dentro e fora do meio acadêmico, nunca conseguiram fazer nem sabem como fazer, acarretando danos ao ensino, à pesquisa e à própria política.

Ao longo de todos esses anos e muito antes da existência do PT, coloquei-me à disposição dos diferentes grupos de mediação, especialmente os envolvidos na defesa da reforma agrária. A reforma agrária não é bandeira do PT e nem mesmo é bandeira propriamente de esquerda, é bandeira da sociedade, dos que nela querem justiça social e dos que nela temem a latifundização do Brasil e a criação de enclaves territoriais e de poder, como vem ocorrendo justamente durante os dez anos de governos petistas. A formação de enclaves territoriais de chineses e de norte-americanos do agronegócio, com pleno conhecimento e cumplicidade do governo, é um fato alarmante que não tem recebido a devida resposta política dos que se tornaram donos das lutas pela reforma agrária, pelo fim da escravidão e pela justiça social no campo.

A dúvida de Heleieth sobre minha suposta posição política é a dúvida de uma pessoa que não conhece o assunto nem me conhece e mesmo assim se póe a julgar o caráter de terceiros. Essa dúvida situa-a no complicado grupo autoritário que considera filiação a partido, especialmente ao PT, como título acadêmico, o partido colocado antes da ciência e até contra ela.

Mas Heleieth vai adiante, ainda referindo-se a mim: "Uma vez ele mandou uma entrevista de dezessete páginas laudatórias em relação ao Fernando Henrique, dizendo que ele estava fazendo uma belíssima modernização do Estado. Nesse dia eu não aguentei e escrevi: 'olha, eu li até a décima primeira página porque não tenho tempo de ler uma entrevista com dezessete páginas, mas eu discordo da primeira até a décima primeira”' (p. 141). Não dei nenhuma entrevista laudatória sobre quem quer que seja (poderia tê-la dado!), não dou entrevistas laudatórias nem escrevo textos laudatórios.
Eu nunca teria enviado um texto meu a Saffioti. Não era minha interlocutora e eu mal a conhecia. De qualquer modo, no meio acadêmico, é sempre arriscado enviar textos a pessoas que leem apenas dois terços de algo e já firmam juízo sobre o texto e o autor. Seria o mesmo que ler apenas duas de cada três linhas de um livro e achar que leu o livro inteiro, a chamada leitura dinâmica. É provável que ela esteja se referindo a um artigo que me foi solicitado por João Brasílio Sallum Júnior, do meu departamento, sobre a questão agrária. Destinou-se a um número especial de Tempo Social-Revista de Sociologia da USP, de avaliação do primeiro governo de Fernando Henrique Cardoso. O texto foi, depois, incorporado ao meu livro Reforma agrária: o impossível diálogo (Edusp, 2000).

Para legitimar o absurdo dessa opinião infundada, ela acrescenta, a meu respeito: "Eu me dou muito bem com ele, nós somos grandes contadores de piada... [...] Hoje somos bons amigos" (pp. 141-142). Fui docente da USP durante 38 anos. Vi Heleieth Saffioti em apenas seis ocasiōes: em duas delas, em bancas de concursos de Araraquara. Fiquei sabendo de seu interesse por piada em dezembro de 1976, quando participei de um seminário sobre mão de obra volante, em Botucatu. Havia um número grande de participantes. Estávamos hospedados num mesmo hotel. No final de um dos dias, esperávamos no bar do hotel a hora do jantar: Octavio Ianni, Tamás Szmerecsányii, Rosa Esther Rossini, creio que Oriowaldo Queda, e eu. Conversávamos. Ianni me perguntou alguma coisa sobre a pesquisa que estava iniciando na região amazônica, sobre os conflitos fundiários. Em algumas regiōes, eu entrava com apoio da Pastoral da Terra. Estava mencionando alguma ocorrência grave com um grupo de freiras, quando Heleieth chegou, ouviu um pedaço da conversa e disse, rindo: "Oba! Adoro piada de sacanagem de padre e freira". Tive que explicar-lhe que o teor da conversa era bem outro, o que a irritou.

Eu tinha, sim, interesse por piadas, pois adotara na pesquisa uma variante da pesquisa-ação ou pesquisa-participante, um método adotado por Roger Bastide e Florestan Fernandes, em meados dos anos de 1950, na pesquisa sobre o negro em São Paulo, e formalizado pelo colombiano Orlando 
Fals-Borda. Como parte da técnica adotada, fazia palestras ou dava cursos compactos de dois ou três dias para agentes de pastoral, militantes sindicais, trabalhadores e, em algumas regiōes, índios. Era muito cansativo para eles. Havia intervalos e sempre alguém puxava um cântico ou uma piada. Passei a contar piadas sobre a ditadura, cuja política agrária era um problema na vida dos participantes.

Fui juntando material desse tipo. Pensei em organizar, numa das reunióes da SBPC - Sociedade Brasileira para o Progresso da Ciência - uma sessão de sociologia do chiste. Alguém me sugeriu que falasse com Oracy Nogueira, que aparentemente havia escrito um artigo a respeito. Oracy achou a ideia boa, mas não escrevera esse artigo. Só em novembro de 2008 tive oportunidade de participar do Moitará da Sociedade Brasileira de Psicologia Analítica, em Campos do Jordão, cujo tema foi o humor, ocasião em que falei sobre "O fundamento urbano do anedotário caipira". Minhas anedotas nada tinham a ver com as anedotas de Saffioti, nem na forma nem no conteúdo nem na função.

Ela diz que "no passado nós tivemos uma briga muito feia, através de um jornal chamado Movimento. O Martins foi para o Pará estudar os conflitos de terra, voltou e escreveu um artigo para o $\mathrm{Mo}$ vimento dizendo que os homens faziam a guerra, se defendiam dos ataques e as mulheres ficavam dentro de casa cuidando dos filhos, da casa e não botavam a cara para fora da janela, porque essa era a divisão do trabalho que se podia aceitar. E que se uma feminista lesse o que estava publicando iria ficar muito brava. Então comecei uma polêmica com ele que só terminou quando ele decidiu não responder mais, mas durou meses" (pp. 141-142). Creio que se trata de um artigo em duas partes ("O campo está lutando e precisa ser ouvido"), publicado em 1980 no jornal Companheiro, um jornal alternativo de esquerda, e não no jornal Movimento, também alternativo de esquerda, do qual fui colaborador eventual. Nele me refiro à estratégia de luta adotada pelas comunidades rurais na região amazônica, onde eu fazia extensa e demorada pesquisa sobre os conflitos fundiários. Eu não fui para o Pará: fui também ao Pará, várias vezes. Minha pesquisa me tomou longos anos e resultou no livro Fronteira: a degradação do outro nos confins do humano (Con- texto, 2012). Heleieth não era familiarizada com o tema. Não podia entender que nesses conflitos se matava e se morria. Eu mesmo fui ameaçado de morte mais de uma vez. A divisão do trabalho alcançava e abrangia a luta fundiária, de modo a proteger a família. Escrevi uma carta para o jornal dando um esclarecimento, pensando sobretudo nos leitores do jornal. $\mathrm{O}$ assunto terminou ali. Heleieth quis contestar meu texto para fazer militância feminista e não para debater os resultados parciais de uma pesquisa sociológica. Não houve polêmica e só na imaginação dela a "polêmica" durou meses. Nenhum jornal ou revista tem espaço para isso.

Aí entra o próprio entrevistador: "Ele sempre foi radical em termos de reforma agrária. O Juarez Brandão Lopes está envolvido com essa área também em Brasília” (p. 142). Sempre fui sociólogo (e não radical) em relação à reforma agrária, apontando a dinâmica variável de suas determinaçôes, a diversidade dos projetos sociais e políticos que se escondem sob essa rubrica, as incertezas que a demarcam, os oportunismos que nela se infiltram, avanços e recuos, como o do PT. O partido assumiu o projeto de reforma agrária dos grupos mais radicais, como a Comissão Pastoral da Terra (CPT) e o Movimento dos trabalhadores Sem Terra (MST). Três meses depois da posse de Lula, ele mesmo demitiu o presidente do Incra, que vinha desses grupos e que ele próprio havia nomeado. No poder, o PT foi recuando em relação ao assunto: criou o Bolsa Família para esvaziar a pressão desses grupos. Antes de terminar seu governo, Lula já estava publicamente comprometido com o agronegócio, definindo seus representantes como heróis nacionais. Em 2013, Dilma Rousseff não fez uma única desapropriação de terras para a reforma, coisa que não aconteceu em nenhum dos governos anteriores, nem mesmo nos governos militares. A realpolitik prevaleceu sobre o radicalismo dos grupos que se agregaram ao PT por motivos bem diversos dos motivos de Lula e dos petistas que definem o perfil atual do partido.

Heleieth pula adiante: "O Martins está trabalhando com o Juarez na pesquisa. A Maria Aparecida Moraes Silva - que foi minha aluna de graduação [...] foi convidada pelo Martins para participar dessa pesquisa. Ela está fazendo sobre um assenta- 
mento perto de Araraquara. Ela entrou na pesquisa na seguinte condição: aquilo que encontrasse, ela escreveria, com autonomia sobre o seu pedaço. $\mathrm{O}$ acordo foi assim" (p. 142). A história é bem outra. Juarez era diretor do Nead, designado por Raul Jungmann, que era o ministro do Desenvolvimento Agrário do governo de Fernando Henrique Cardoso. Jungmann foi o ministro que esteve mais próximo de realizar a reforma pretendida pela CPT e até mesmo pelo MST. Foi o ministro mais disposto a conversar. Mas nessa altura, as duas entidades estavam fazendo oposição ao governo FHC para viabilizar a candidatura de Lula. Perderam uma oportunidade de ouro.

Juarez promoveu um seminário em Brasília, sobre reforma agrária, de que participaram pesquisadores de várias regiōes, vários do PT. Desse seminário nasceu a ideia de fazer uma avaliação da reforma agrária brasileira, não só a que vinha sendo realizada pelo então governo. Ocorreu em Brasília, no Nead, uma reunião preparatória e foram constituídos dois grupos de pesquisa, cada um utilizando uma metodologia diferente. Juarez me convidou para coordenar um dos grupos e propor o respectivo método. Convidei cinco pesquisadoras minhas conhecidas, de reconhecida competência na pesquisa e estudo da questão agrária, para que cada qual realizasse um estudo de caso em cinco diferentes estados: Eliane Cardoso Brenneisen (para o Paraná), Maria Aparecida Moraes Silva (para São Paulo), Maria da Conceição Quinteiro (para Goiás), Maria de Nazareth B. Wanderley (para Pernambuco) e Sônia Barbosa Magalhães (para o Pará). Elas propuseram o respectivo local de pesquisa. A ninguém foi imposto ou exigido qualquer coisa. Tratava-se de uma pesquisa e não de um comício. E de ninguém se aceitou qualquer imposição. "Acordo" restritivo de natureza partidária só existiu na imaginação de Heleieth, que pelo visto pretendia tutelar sua antiga aluna. Sendo as cinco pesquisadoras pessoas adultas e experimentadas, cada qual saberia o que fazer. Se eu soubesse que o convite estava constrangendo qualquer uma delas, eu as teria colocado à vontade para participar ou não da pesquisa. Ninguém me disse nada, os trabalhos foram feitos e, como programado, reunidos num livro editado por mim, com um primeiro capítulo, meu, sobre o sujeito da reforma agrária (Travessias: a vivência da reforma agrária nos assentamentos, Editora da UFRGS, 2003).

Trindade achou que devia perguntar a Heleieth Saffioti: "O Martins continua na sociologia agrária?” (p. 142). Ela não era minha porta-voz! Por que ele não perguntou a mim? E ela, com notável desenvoltura, atrevimento e pretensa familiaridade com meus assuntos, inventa, responde e calunia: "Continua na seguinte base: ele nunca deu curso de pós-graduação. Nós sabemos que para dar um bom curso na pós-graduação a gente precisa preparar muito. Ele só dá na graduação, por isso a cada dois anos ele publica um livro. E faz muitos anos que ele não tem um só orientando, ele não quer, não há quem o convença. Eu acho que é obrigação para quem está na universidade”. Sempre soube, perfeitamente, quais eram minhas obrigaçôes na universidade.

Doutorei-me em 1970, fui credenciado para a pós-graduação em 1971 e comecei a dar cursos de pós em 1972. Dei-os até 1993, durante 21 anos, sem me afastar dos cursos de graduação. Nesse período, introduzi o seminário semanal de pós-graduação das sextas-feiras, em semestres alternados, sobre o método dialético na obra de Karl Marx. O seminário estendeu-se por doze anos. Através de acordo feito com os alunos, os que fossem completando os créditos eram convidados a continuar, sem créditos. Não era apenas um curso: era um projeto intelectual. Estávamos fazendo a leitura metodológica da obra de Marx, desde os volumes preparatórios de $O$ capital, passando duas vezes pelo próprio $C a$ pital, pelas obras filosóficas, pelas cartas, pelos textos políticos. $\mathrm{O}$ que importava não era a obtenção de créditos em primeiro lugar, mas a obtenção de conhecimento. É o que se espera da graduação e da pós-graduação.

Esses doze anos foram completados com seis anos de leitura da obra de Henri Lefebvre, tendo em conta a questão do método, na mesma base. Lefebvre foi quem propôs o retorno a Marx sociólogo. Os dezoito anos de leituras sobre a questão da dialética culminaram no colóquio "A aventura intelectual de Henri Lefebvre", cujos trabalhos foram publicados em livro: Henri Lefebvre e o retorno à dialética (Hucitec, 1996). Formei uma geração inteira de professores universitários, que é uma das 
principais funções dos cursos de pós-graduação. Deixei a pós em 1993 porque decidi desenvolver uma nova metodologia no ensino de graduação. $\mathrm{Na}$ USP tínhamos e temos cursos diurnos e noturnos. A carga horária era regulada pela famosa portaria GR-1.407, que distribuía as 40 horas semanais do docente por um número fixo de horas para pesquisa (50\%), para aulas (de graduação e de pós) e para extensão, orientação e colóquios com os estudantes. Ao deixar de dar as aulas de pós, preenchi o horário com mais aulas de graduação, como era da norma vigente. Dei meu último curso de graduação em 2001, já me preparando para a aposentadoria em 2003. Nunca, aliás, deixei de dar cursos de graduação. Com Marialice Mencarini Foracchi, modificara e atualizara o curso de Introdução à Sociologia que há muitos anos havia sido organizado por Florestan Fernandes. Introduzi no currículo dois cursos novos e inovadores, de novas perspectivas na sociologia, em linha teórica própria: o curso de sociologia da vida cotidiana, um curso pioneiro de teoria sociológica, e o curso de sociologia visual, em linha oposta à de Howard Becker, pai fundador desse campo de conhecimento.

Além disso, até por razôes de pesquisa, dediquei-me à chamada prestação de serviços à comunidade, a extensão universitária, com palestras e cursos para grupos populares na periferia e no remoto interior do Brasil. Dei 68 cursos para trabalhadores, agentes de pastoral e sindicalistas. Fiz 66 palestras para trabalhadores rurais e urbanos e fiz 156 conferências em universidades daqui e de outros países. Participei de 76 congressos e seminários, com apresentação de trabalhos, e de 111 bancas examinadoras. Dei assessoria, gratuita, a quatro organizações humanitárias internacionais. Durante doze anos e quatro mandatos sucessivos fui membro da Junta de Curadores do Fundo Voluntário da ONU contra as Formas Contemporâneas de Escravidão, em Genebra, designado pelo Secretário Geral. Coordenei, no Ministério da Justiça, durante o ano de 2002, a comissão federal de alto nível que preparou o Plano Nacional de Erradicação do Trabalho Escravo e Infantil. Nunca aceitei um centavo por esses trabalhos e nunca deixei de cumprir minhas obrigaçôes docentes e de pesquisa. Quando foi necessário ausentar-me por mais tempo, repus as aulas pontualmente no mesmo semestre, no semestre anterior ou no semestre seguinte.

Não só um curso de pós-graduação pede esforço e preparação. O de graduação também e até muito mais. Quem deixa essa norma de lado, certamente, está lesando seus alunos de graduação.

Instituí no meu curso de graduação as aulas de rua, em fins de semana, bem como a pesquisa de campo sobre tema relacionado com o curso de sociologia da vida cotidiana, sem qualquer redução no horário das aulas na sala de aula. A partir de um projeto de pesquisa, escrito por mim, alunos do diurno e do noturno, de cada ano, faziam em feriados e fins de semana uma pesquisa. Acompanhados por mim apuravam e analisavam os resultados e finalmente escreviam a monografia respectiva. Passei a ser, também, orientador da elaboração de monografias de graduação. Foram quatro pesquisas por eles realizadas nesse período: sobre sonhos, mediante a formação de um banco de sonhos; sobre a vergonha e o decoro como técnica social; sobre a mentira, também como técnica social; sobre o desemprego e o cotidiano do desempregado. Os trabalhos escritos pelos alunos, em relação aos dois primeiros temas, foram publicados em livros: (Des) figuraçôes: a vida cotidiana no imaginário onírico da metrópole (Hucitec, 1996); Vergonha e decoro na vida cotidiana da metrópole (Hucitec, 1999). Os outros dois trabalhos não foram publicados: um por falta de meios; outro porque não concluído em virtude de uma greve que interrompeu a atividade.

Heleieth Saffioti, em sua entrevista, procura apresentar-me como um gazeteiro, coisa que nunca fui. O íntegro e integral cumprimento de minhas obrigaçôes na universidade está descrito em espaço um num currículo de 77 páginas, tipo 12, e 20 metros de comprimento, bem medidos. Boa parte desse currículo está também no Lattes e pode ser consultado por qualquer interessado.

Tenho um defeito de educação que em grande parte responde por esse meu empenho no trabalho. Atribuo-o ao fato de ter ido para a fábrica aos 11 anos de idade e de ter assimilado, muito cedo, a disciplina fabril. A precocidade do trabalho deforma o caráter da criança e do adolescente, que se tornam indefesas vítimas de um feitor interiorizado para sempre. 
Quando decidi estudar à noite, já trabalhando, minha jornada passou de 8 horas por dia para 13 a 14 horas por dia e até hoje é assim, mesmo com 75 anos de idade e já aposentado. Tive que aprender a administrar meu tempo para não ser derrotado pela dupla jornada de trabalho e estudo. Uma decorrência foi que me tornei, também, um autodidata, o que não foi necessariamente bom nem pedagogicamente correto.

Outro fato é que, no subúrbio operário, fui educado nos valores do calvinismo, o que me ajudou e muito a compreender e valorizar minha vida de dupla jornada. Nessa orientação religiosa, na da impessoalidade da vocação, cada um é chamado, cotidianamente, a multiplicar os talentos da parábola bíblica, que não são seus nem para si. Cada um, portanto, compete consigo mesmo e dá um passo de cada vez. É preciso saber escolher o caminho: o caminho fácil, tentador e de prazeres, e também o caminho da maledicência e da inveja, é o caminho que não leva a lugar nenhum; o caminho difícil, o que exige esforço, disciplina e paciência, é o que dá a recompensa de chegada ao cume da montanha. $\mathrm{O}$ livro mais editado depois da Bíblia é o livrinho de John Bunnian, O peregrino, obra inglesa do século XVII, que norteia a vida dos protestantes.

Enquanto meus colegas liam o livro vermelho de Mao Tsé Tung, eu lia o livro vermelho do John Bunnian, que tenho até hoje. No tamanho e no formato, muito parecidos. A própria fábrica em que trabalhei mais tempo e onde me tornei adulto, a fábrica que me pagou o curso secundário noturno, me pôs nas mãos e me estimulou a ler Mensagem a Garcia, de Elbert Hubbard, um livreto dos fins do século XIX - a história de um homem cumpridor da missão que lhe fora designada durante a guerra pela independência de Cuba. Uma versão fabril da obra de Bunnian. Frequentemente nos esquecemos de que existe uma pedagogia da fábrica e que a fábrica é também uma escola.

Mas a própria USP, de tradições protestantes ocultas, difundia a ética de Calvino. Quando estava fazendo o curso de ciências sociais, Octavio Ianni, em seu curso Métodos e Técnicas de Pesquisa, não só nos mandou ler $A$ ética protestante e o espírito do capitalismo, de Max Weber, que analisou conosco, como em conexão com essa leitura recomen- dou que lêssemos Os Buddenbrooks, de Thomas Mann, e a Autobiografia, de Benjamin Franklin. O livro de Franklin contém a famosa orientação para o uso das horas do dia e de cada dia da semana, o calvinismo transformado em "plano de trabalho" e de vida. Fernando Henrique Cardoso, cuja mãe, aliás, fora presbiteriana, recomendava aos alunos, no limiar da pós-graduação, a prudência de não se deixarem abater antes de começar, atemorizados pela ideia de escrever o primeiro livro, a tese: "escrevam três páginas por dia, todos os dias, ao fim de alguns meses terão uma tese ou um livro". Uma recomendação claramente calvinista. Florestan Fernandes, como me contou Antonio Candido, adotou uma disciplina germânica de trabalho, portanto protestante, por sugestão do antropólogo Emilio Willems, católico. Um dia convocou-me para uma conversa sobre minha pesquisa de mestrado, em sua casa, no Brooklin, às 7 horas da manhã. Para que ele não perdesse tempo, já que era entrevista não programada em sua rotina, a conversa foi no banheiro, enquanto ele fazia a barba!

$\mathrm{Na}$ orientação dos valores dessa cultura, se subo o primeiro degrau, conseguirei subir o segundo e depois o outro e mais outro, a escadaria inteira. Mas a meta é sempre, e apenas, o passo seguinte, o passo do dia. Sou minha própria medida e faço o que posso e devo e não o que o outro faz. Ninguém é melhor do que ninguém. Mas deve ser sempre melhor do ele próprio é. O prazer do calvinista é o de vencer-se e não o de vencer alguém. Tudo repousa no pressuposto da salvação pela fé, do móvel interior da decisão pessoal e intransferível. Ninguém é cópia de outro, é dever de si mesmo. Um calvinista nunca passaria pelo sofrimento que Heleieth demonstra nas duas páginas de sua entrevista em que a mim se refere de maneira tão ressentida, tão descabidamente derrotada e tão desrespeitosa. Elegeu a pessoa errada como referência de seu mal-estar. Eu não estava competindo com ela nem estava interessado em nada do que ela pudesse pensar a meu respeito nessa perspectiva pobre e distorcida. Se ela tivesse conversado comigo, eu lhe teria poupado todo esse inútil e descabido sofrimento interior. Nada do que consegui era dela. Nada do que ela conseguiu era meu.

Um terceiro entrevistado que a mim se refere de maneira descabida é Antônio Flávio Pierucci. 
Não sei bem porque cargas d'água Helgio Trindade decide emitir um juízo a meu respeito: "O Martins, que trabalhava com Sociologia Agrária deu numa virada com relação ao Fernando Henrique. Hoje ele é um dos ideólogos de uma certa posição completamente diferente do [que] ele tinha antes, completamente a favor. Ele foi orientador do José Vicente, então tem alguma coisa aí que ultrapassa" (p. 270). Se tivesse lido meus trabalhos, Helgio nunca faria essa pergunta a ninguém. E Flávio Pierucci, sem saber exatamente do que se tratava, diz: "Ultrapassa". Ultrapassa o quê? Pierucci nunca teve a mínima ideia do que era meu trabalho, mal conversou comigo uma dúzia de vezes sobre fatos diversos. Nunca trabalhei com sociologia agrária, até porque sociologia agrária não existe, só na cabeça de quem está longe do assunto. Nem com sociologia rural. Expus isso, há muitos anos, no livro Introdução crítica à sociologia rural (Hucitec, 1981). Os temas rurais não fazem necessariamente uma sociologia rural, do mesmo modo que estudar a classe operária não faz uma sociologia urbana.

Fernando Henrique Cardoso foi meu professor de sociologia no curso de ciências sociais. Nós nos conhecemos desde 1961, há mais de meio século. Tenho por ele o imenso respeito que merece um intelectual de seu porte, além do cidadão exemplar que é. Não sou ideólogo de coisa nenhuma, até porque sei perfeitamente qual a diferença entre ciência e ideologia. Tampouco sou intelectual orgânico, pois outros entenderam que o fora da Pastoral da Terra e do MST. Sou um pesquisador que estuda os movimentos sociais, especialmente os movimentos relacionados com a questão agrária, e que estuda também o comportamento coletivo, caso de minha extensa pesquisa sobre linchamentos no Brasil, predominantemente urbanos.

O fato de me interessar por esses movimentos, e até por eles me empenhar, não me faz seu ideólogo. E o fato de me interessar pelo modo como o Estado lida com eles, nos diferentes governos, tampouco me faz ideólogo de governo. Não me muda de lado porque o meu lado é o do trabalho científico. Só as pessoas que sujeitam a ciência à política partidária fazem essa confusão. Desde 1975 acompanho a tensão dialética entre Estado e movimentos sociais. Apesar de estar no campo adversário à ditadura, não deixei de entender o significado histórico das medidas que o regime militar tomou, por exemplo, em relação à questão agrária. Mas também não deixei de entender e analisar os graves problemas que criou para índios e trabalhadores rurais com sua opção por uma política fundiária subjugada pelo agronegócio. Como não deixei de entender criticamente a opção do PT e seu governo pelo mesmo agronegócio contra uma opção inicial, que se revelou oportunista, de fachada, pelas lutas sociais no campo para ter o apoio eleitoral dos movimentos populares e das igrejas neles envolvidas.

Em certo momento, Pierucci fala da crise da sociologia na USP, crise que teve vários fatores, o mais grave dos quais foi a cassação dos professores pelo regime militar no início de 1969, crise que ele não conheceu. Menciona, na USP, a ida de alguns professores de sociologia e de antropologia para o Departamento de Ciência Política sem mencionar que essa transferência já era parte da estratégia de articulação do Cebrap com um setor da universidade. Atribui-me responsabilidade no caso por (supostamente) ser "arquirrival" de um dos professores que se transferiram. Não sou nem nunca fui rival e menos ainda arquirrival de quem quer que seja. Nem do próprio Flávio Pierucci. Não tenho tempo para isso. Nem perco tempo com isso, com as picuinhas e questiúnculas da vida acadêmica na problemática Faculdade de Filosofia da USP. Se tivesse enveredado por aí, não teria feito carreira ou teria feito uma carreira medíocre.

No entanto, há aí o verdadeiro motivo da menção: "Mas o departamento de sociologia era muito pobre de quadros, era muito caipira, a área de sociologia, entendeu [?]. Depois que passou o grande ciclo dourado é a migração da pesquisa para o centro de pesquisa que era o Cebrap" (p. 270). Pierucci, que só veio a ter contato com a sociologia no Cebrap e veio para o Departamento de Sociologia da Faculdade de Filosofia da USP em 1988, viveu na fantasia de que na USP se dava aula e no Cebrap se fazia ciência: "A área de sociologia ficou muito voltada para dentro, você tinha alguns professores que só eram conhecidos ali dentro e só davam aula". Não leva em conta a dedicação e o empenho de docentes como Luiz Pereira e Marialice Mencarini Foracchi (falecida em 1972) na 
formação pós-graduada de estudantes oriundos de outros estados, como Rio de Janeiro e Goiás, num momento crítico do ensino superior de ciências sociais no Brasil. Personagens do livro, de outros estados, recorreram à USP para fazer seus mestrados ou doutorados, coisa que ele, e muita gente, omite, a começar pelos próprios beneficiados.

Cita depreciativamente suas (e minhas) colegas, chamando-as de "as meninas", como exemplo desse esvaziamento. Dá informaçôes erradas sobre elas, pessoas que estavam lá dando duro na formação de toda uma geração de estudantes, muito antes de ele chegar. Vai mais longe e passa dos limites: “Tem a fase do Luiz Pereira que foi uma fase ruim para a sociologia, pois puxou a sociologia para dentro" (pp. 270-271). Pierucci não conheceu Luiz Pereira. Foi para o departamento três anos depois de sua morte. Provavelmente nem mesmo conheceu sua obra, pois sem formação específica de graduação em ciências sociais enveredou, em pós-graduação, por um campo definido e especializado, o da sociologia da religião, bem distante da sociologia de Luiz Pereira.

O ponto mais grave da intervenção de Pierucci sobre Luiz é este: "Ele era uma pessoa voltada para dentro. Hoje as pessoas, depois da morte de Luiz Pereira - que todo mundo ficou sabendo que morreu de AIDS - tentam entender como se fosse uma pessoa enrustida. Ele não convidava ninguém para ir na casa dele, não se sabia qual era o segredo que guardava. Quando eu entro na USP [...] é a fase que, por uma série de razões, há uma certa agilização: 'vamos trazer pessoas', que abram o departamento de sociologia para fora. Então é quando vem o Sergio Miceli. Eu entrei na USP antes do Sergio". E agrega mais adiante: "o Luiz Pereira é um homossexual...". O que isso tem a ver com os problemas do Departamento de Sociologia? Nada! Que direito tem Pierucci de se referir à vida pessoalíssima de um colega? Nenhum!

Conheci Luiz Pereira, trabalhei com ele vários anos, tivemos nossas diferenças, nunca deixei de respeitá-lo e admirá-lo. Tenho uma versão completamente diferente para a doença e a morte de Luiz. Ele adoeceu quase repentinamente, em pouco tempo se deu conta que já não tinha condições de trabalhar, pediu a aposentadoria, interrompeu a carreira e morreu pouco depois. Vários anos mais tarde, um médico do Hospital do Servidor Público, onde Luiz falecera, encontrou José César Gnaccarini, do nosso departamento, de quem era amigo, e lhe contou que o Hospital costuma reexaminar periodicamente, à luz de novos conhecimentos médicos, os casos de óbitos sem causa definida. $\mathrm{O}$ caso de Luiz foi reexaminado e os médicos chegaram à conclusão de que morrera de Aids e fora uma das primeiras vítimas da doença no Brasil. Inferir que Luiz teve Aids porque era "homossexual" e que, por supostamente ser homossexual, era "enrustido" e que, porque enrustido, não recebia os alunos, pois tinha "um segredo", e que, porque era enrustido, puxou o Departamento de Sociologia "para dentro", é inferir muito mais do que o bom senso recomenda e as evidências sugerem. No caso, o bom senso e o respeito pela memória de nosso colega.

O Departamento de Sociologia perdeu outro professor vitimado por Aids, Eder Simão Sader, que era hemofílico e dependia de transfusōes de sangue, numa época em que a qualidade do sangue era precariamente controlada. Eder não era homossexual. Alguns anos antes da morte de Luiz, houve um primeiro extenso surto de hepatite em São Paulo. A USP promoveu uma vacinação em massa de alunos, funcionários e professores. Do Departamento dois docentes haviam contraído hepatite: Azis Simão, também hemofílico, tio de Eder, que recebeu transfusōes, mas não contraiu nenhuma doença; e Luiz Pereira, que foi tratado à base de um hemoderivado, que poderia estar contaminado.

Não se trata de esconder o que Luiz eventualmente fosse ou de negar-lhe o direito de supostamente ter sido homossexual. A homossexualidade, como a heterossexualidade, é assunto da pessoa. Não é assunto para um livro sobre as ciências sociais no Brasil, que não é um livro sobre a sexualidade dos cientistas sociais brasileiros. Certamente, não há grandeza em atribuir uma crise de departamento universitário ao fato de que alguém fosse homossexual.

Luiz Pereira recebia em sua casa, regularmente, alunas e alunos, mesmo de graduação, mais do que a maioria dos professores, para orientação e troca de ideias sobre tarefas escolares. Sendo seu auxiliar de pesquisa, presenciei isso várias vezes. Eu mesmo, 
aluno de graduação, era recebido por ele diariamente em seu apartamento da rua Caio Prado. $\mathrm{Na}$ rua Maria Antônia os professores praticamente não tinham espaço para receber os alunos. Recebiam-nos em suas casas. A sala que Florestan Fernandes, catedrático, compartilhava com duas funcionárias administrativas tinha cerca de $10 \mathrm{~m}^{2}$. O próprio Luiz não tinha sala na escola.

Com todo o respeito pelos docentes que chegaram tarde ao departamento, em época de relativa liberdade, e colheram frutos semeados por aqueles que lá já se encontravam, a sociologia da USP não estava esperando a vinda de um messias salvador. Nossa única espera era a do retorno dos professores cassados pela ditadura. Porque era justo que voltassem. E não voltaram.

Pierucci se engana quando afirma que a USP ficou com as aulas e o Cebrap com a pesquisa. $\mathrm{Na}$ USP ficamos com as aulas e a pesquisa. E o Cebrap especializou-se em pesquisa porque essa era a alternativa. Todos nós sabíamos, desde o começo, que o Cebrap, ou qualquer outra instituição similar, não tinha condições de se transformar num instituto de pesquisa do tipo possível na universidade pública. Octavio Ianni chegou a conversar comigo sobre isso, consciente das limitaçôes que ia enfrentar no Cebrap. Não obstante fossem seus membros pesquisadores renomados e professores brilhantes, nenhum pesquisador do Cebrap superou ali a obra que realizara na Universidade de São Paulo. Basta comparar. O Cebrap tinha as limitações próprias da pesquisa de resultados, a pesquisa instrumental. Quem financia uma instituição assim quer resultados em prazo certo para responder questôes definidas. Uso uma distinção de Henri Lefebvre para indicar a diferença sociológica entre instituições de pesquisa com essa limitação e instituições de pesquisa sem essa limitação: aquelas cujo resultado é o produto, na lógica da indústria, e aquelas cujo resultado é a obra, na lógica da criação e da invenção, na lógica da arte, como sugere Robert Nisbet em famoso ensaio, $A$ sociologia como forma de arte.

Lamento ter sido colocado, abusiva e indevidamente, no desconforto e na obrigação de invocar meu direito de dar esclarecimentos desta natureza para desfazer as manifestaçôes que aqui contesto. Faço-o para que o desrespeito de alguns mortos não recaia como um pesadelo sobre a honra dos vivos. A palavra do morto é sempre penúltima palavra, nunca a última, alcançado que foi pela definitiva derrota da morte. $\mathrm{O}$ direito de opinião tem um limite no direito do outro, que é o de ter sua verdade reconhecida e respeitada, quando ameaçada pelas expressões de sentimentos menores do que aqueles que cabem no mundo do conhecimento e da ciência.

\section{Notas}

1 O livro contém entrevistas com: Luiz de Castro Faria, Juarez Brandão Lopes, Octavio Ianni, Roberto Cardoso de Oliveira, Ruth Cardoso, Heleieth Saffioti, Carlos Estevam Martins, Maria do Carmo Campello de Souza, Silvio Coelho, Eduardo Kugelmas, Antônio Flávio Pierucci, Lygia Sigaud, Gilberto Velho, Gildo Marçal Brandão e Maria D’Alva Kinzo.

2 Em 1994, quando eu era professor titular da Cátedra Simón Bolivar, da Universidade de Cambridge, novo catedrático, fui convidado pelo Master de Saint John's College para as cerimônias anuais de celebração do patrono, São João Batista. No solene serviço religioso, na capela do College, o sermão do pregador foi sobre "A influência do calvinismo no desenvolvimento da ciência em Cambridge".

3 Na USP, estatutariamente, as funções de reitor, diretor de unidade e chefe de departamento são ocupadas por professores que tenham feito o concurso para professor titular e sido aprovados, concurso acessível aos livre-docentes e só excepcionalmente, mediante o reconhecimento do notório saber pela congregação, por candidato sem essa ou outra titulação. Nas ciências sociais houve um único caso de docente, Francisco de Oliveira, que não tinha doutorado e se tornou professor titular. Nas unidades e nos departamentos, podem ser diretores e chefes os docentes que não sejam titulares desde que não os haja ou desde que os desse nível hierárquico não possam, justificadamente, assumir a função. Nesse caso, são convocados sucessivamente os dos seguintes níveis hierárquicos, por antiguidade no título. Havendo mais que um de mesmo título, é feita eleição. Na época do caso de Carmute, as três áreas estavam reunidas num único departamento, o de $\mathrm{Ci}$ ências Sociais, que tinha quatro professores titulares: Ruy Coelho, Azis Simão, João Baptista Borges Pereira e Juarez Rubens Brandão Lopes. Portanto, antes de mim, que era apenas professor assistente-doutor, ha- 
via pelo menos uns dez potenciais candidatos, vários deles ansiosos por essa posição, não só pelo poder, mas também pelo adicional agregado aos vencimentos, que pode ser incorporado à aposentadoria.

JOSÉ DE SOUZA MARTINS é sociólogo, professor emérito da Faculdade de Filosofia, Letras e Ciências Humanas da Universidade de São Paulo; fellow de Trinity Hall e Simon Bolivar Professor da Universidade de Cambridge (1993-1994); professor honoris causa da Universidade Federal de Viçosa, MG (2013); doutor honoris causa pela Universidade Federal da Paraíba (2013). E-mail: jose38@uol.com.br.

\section{Determinantes da descentralização}

Tulia Falleti. Decentralization and subnational politics in Latin America. Cambridge, Cambridge University Press, 2010. 285 páginas.

\section{Cecilia Viana}

Críticos e defensores da descentralização têm em comum ao menos a premissa de que a transferência de recursos, responsabilidades e autoridade resultam em maiores poderes para os governos subnacionais. Em Decentralization and subnational politics in Latin America, Tulia Falleti coloca essa afirmação à prova. Partindo de referenciais teóricos como a dependência da trajetória, a evolução institucional e os efeitos do tempo em processos políticos, a autora discute o grau de mudança no balanço de poder entre níveis do governo resultante da descentralização. Esse é o primeiro livro autoral de Falleti, cujo conjunto de publicações acadêmicas se centram em temas como descentralização, federalismo, democracia e política comparada na América Latina. Professora da Universidade da Pensilvânia e de nacionalidade argentina, Falleti recebeu prêmios por alguns de seus trabalhos, entre os quais o livro aqui resenhado.

Sua abordagem se dá a partir da teoria sequencial da descentralização. Nessa proposta metodológica, a ordem em que ocorrem os três tipos de descentralização (administrativa, fiscal e política) depende dos interesses territoriais dominantes e determina o balanço final de poder. Os casos da Argentina, da Colômbia, do Brasil e do México analisados no livro indicam que os resultados da descentralização variam, e os procedimentos metodológicos empregados na análise se mostram úteis para explicar o porquê dessa variação.

Uma das principais contribuições do livro para a literatura de descentralização é a atenção dada aos interesses territoriais dos atores. $\mathrm{Na}$ análise de Falleti, quando atores se unem em torno do nível de governo (central, intermediário ou local) que defendem, esses interesses predominam sobre coalizões partidárias. Sem restringir os participantes ao executivo dos governos, Falleti defende que os representantes do governo central irão preferir a descentralização administrativa, seguida da fiscal e 